\title{
Screening Almond Rootstocks for Sources of Resistance to Armillaria Root Disease
}

\author{
Kendra Baumgartner ${ }^{1}$ and Phillip Fujiyoshi \\ U.S. Department of Agriculture, Agricultural Research Service, Crops \\ Pathology and Genetics Research Unit, Davis, CA 95616
}

Craig Ledbetter

U.S. Department of Agriculture, Agricultural Research Service, Crop Diseases, Pests and Genetics Research Unit, Parlier, CA 93648

\section{Roger Duncan \\ University of California Cooperative Extension, Stanislaus County, Modesto, CA 94358}

\section{Daniel A. Kluepfel}

U.S. Department of Agriculture, Agricultural Research Service, Crops Pathology and Genetics Research Unit, Davis, CA 95616

Additional index words. Armillaria mellea, Armillaria tabescens, clonal rootstocks, Prunus dulcis, Prunus persica

\begin{abstract}
Prunus dulcis (almond) is one of the most susceptible horticultural crops to Armillaria root disease. Resistance to Armillaria mellea and Armillaria tabescens, the geographically isolated causal fungi that attack almond and closely related Prunus persica (peach), has been evaluated in studies of almond, peach, and other Prunus rootstocks, but not in one comprehensive study. We evaluated the relative resistance to $A$. mellea and $A$. tabescens of six clonally propagated almond and peach rootstocks (Bright's 5 , Empyrean 1, Hansen 536, Krymsk 1, Krymsk 86, and Lovell) in comparison with that of clonally propagated Marianna 2624 rootstock (resistant control) and clonally propagated Nemaguard rootstock (susceptible control). Replicate clones used in the growth chamber assay were micropropagated and rooted in vitro before inoculating the culture medium with Armillaria spp. At 2 months, the most resistant and susceptible rootstocks were Krymsk 86 and Hansen 536, respectively, with $27 \%$ vs. $89 \%$ mortality. This finding was consistent among two isolates of $A$. mellea and one isolate of $A$. tabescens in three replicate experiments. Our finding of low mortality among Krymsk 86, Krymsk 1, and Marianna 2624, which all share Prunus cerasifera (Myrobalan plum) parentage, is consistent with past reports of resistance in the field to $A$. mellea, but conflicts with reports of susceptibility to $A$. tabescens. Resistance to $A$. tabescens of genotypes with Myrobalan plum parentage in our assay may reflect the simplified rooting environment of tissue culture medium, which does not perfectly mimic a field trial, in which biotic and abiotic factors may affect host resistance. Nonetheless, our growth chamber assay may provide a more rapid alternative to identify sources of resistance for breeding and to screen progeny of such crosses.
\end{abstract}

Prunus species are among the most susceptible tree crops to Armillaria root disease in the northern hemisphere (Baumgartner et al., 2011). In the southeastern United States, the causal species is $A$. tabescens

\footnotetext{
Received for publication 18 Apr. 2017. Accepted for publication 13 July 2017 .

Funding provided by the Almond Board of California. Tissue culture stocks of rootstocks were provided by Javier Castillon (Duarte Nursery/Dry Creek Laboratories, Hughson, CA).

Review of this manuscript and isolates of Armillaria tabescens from Guido Schnabel (Plant \& Environmental Sciences Department, Clemson University) are gratefully acknowledged.

${ }^{1}$ Corresponding author. E-mail: kendra.baumgartner@ ars.usda.gov.
}

(Schnabel et al., 2005) and it limits the productive lifespan of peach and necessitates premature removal and replanting of entire orchards (Schnabel et al., 2012). Outside the United States, there are similar reports of stonefruit susceptibility from Mexico (EliasRoman et al., 2013), Europe (Guillaumin et al., 1989), the United Kingdom (Kable, 1974), Japan (Sasaki and Jinno, 1975), and China (Qin et al., 2007). The causal fungi across these regions, $A$. mellea or $A$. tabescens, colonize and kill woody roots and then decompose the root wood as substrate. Such destruction to the root system over time reduces yield and diminishes growth capacity (Baumgartner, 2004), eventually killing infected trees.

Management of Armillaria root disease focuses mainly on preplant soil fumigation.
Unlike most root pathogens, which produce spores that lie dormant in the soil (e.g., Phytophthora), Armillaria persists in its vegetative stage-mycelium-within woody roots left in the soil after clearing infected trees (residual roots). We have recovered viable $A$. mellea mycelium from residual roots, in orchard and vineyard soil, originating from tree crops and forest trees $10+$ years after they were cleared (Baumgartner and Rizzo, 2002; Rizzo et al., 1998). Fumigants such as methyl bromide are only effective to the extent that they reach and penetrate residual roots (Bliss, 1951; Munnecke et al., 1981). Injection of the systemic fungicide propiconazole to living trees reduced symptom severity in almond on Lovell rootstock (Adaskaveg et al., 1999), but this approach can be cumbersome for large disease centers. Another approach to postinfection management is root collar excavation, although this approach must be carried out in advance of severe symptom development (Baumgartner, 2004; Schnabel et al., 2012).

A 10-year field trial in France of ungrafted Prunus rootstocks (Guillaumin et al., 1989) identified $A$. mellea-resistant and susceptible Prunus species. Peach (GF305) and peach hybrids [S3400 (Prunus besseyi $\times$ peach) and 'Paramount', aka GF677 (almond $\times$ peach)] were most susceptible. By contrast, rootstocks with plum backgrounds ['Myrabi' (Myrobalan), GF43 (Prunus domestica), Marianna GF8-1 (Myrobalan $\times$ Prunus munsoniana)] were the most resistant. Similar results of lower mortality among rootstocks with plum parentage including Myrobalan (P. cerasifera), P. munsoniana, or both were found in a field trial in California (Thomas et al., 1948). Interestingly, in the French study, hybrids of peach and Myrobalan \{'Ishtara' [Myrobalan $\times($ Myrobalan $\times$ peach $)$, 'Myran' (Myrobalan $\times$ peach) $\}$ were resistant, suggesting that resistance in Myrobalan is a dominant trait. Mortality was related to the degree of infection, such that rootstocks with low mortality also had very few infected roots, and a low proportion of plants were girdled by root collar infection. These findings suggest that the Armillaria resistance in Myrobalan, and possibly other plums, is true resistance, rather than tolerance. Resistant rootstocks became infected, but infection was restricted to a low level. If Myrobalan were "tolerant," we would expect low mortality, in spite of high levels of root infection.

Field trials examining rootstock resistance to soil-borne pathogens are informative, but they are lengthy and cannot be modified after planting to accommodate new rootstocks. Unfortunately, inconsistent infection in the greenhouse has been a bottleneck to Armillaria research. Repeated attempts by researchers to modify each step of the greenhouse infection assay have been unsuccessful at counteracting the high proportion of plants that escape infection and the slow rate of infection (Guillaumin et al., 1989; Mansilla et al., 2001; Singh, 1980). Rather than trying to recreate a field infection of plants grown in pots in a soil-based medium, 
we grew plants in a tissue culture medium, which supports both plants and pathogen (Baumgartner et al., 2010; Baumgartner et al., 2013). With this infection assay, we have overcome the major barriers of the greenhouse approach, namely, eliminating "escapes," and bringing about consistent and repeatable levels of mortality. We can replicate experiments within a 1-year period to identify promising rootstock genotypes for later, more lengthy evaluation in the field.

Our objective was to use this infection assay to identify Armillaria-resistant rootstocks for almond, by screening a set of eight clonally propagated, commercially available rootstocks, which are graft-compatible with almond. Plant genotypes were selected based on input from University of California Cooperative Extension crop advisors and almond researchers, with a focus on the following criteria: widespread use in California (Lovell and Nemaguard), building interest for new plantings (peach $\times$ almond hybrids Bright's 5, Empyrean 1, and Hansen 536), or likely to be Armillaria resistant (Myrobalan plum hybrids Krymsk 1 and Krymsk 86).

\section{Materials and Methods}

Plant propagation and inoculation. Our approach aimed at propagating rootstocks in vitro and inoculating the growth medium with Armillaria. At 2 months postinoculation, we tallied the number of dead plants per rootstock and then used percent mortality as a measure of resistance (Baumgartner et al., 2013). Stocks of the rootstocks in tissue culture were obtained from Duarte Nursery/ Dry Creek Laboratories (Hughson, CA) and confirmed before the experiment to root consistently in vitro.

Provided rootstock in vitro cultures were maintained and proliferated on a medium consisting of Quoirin and Lepoivre basal salts (Quoirin and Lepoivre, 1977), Murashige and Skoog vitamins (Murashige and Skoog, 1962), 3\% sucrose, $4.4 \mu \mathrm{M}$ benzyladenine, $0.49 \mu \mathrm{M}$ indolebutyric acid, and $0.6 \%$ agar gel. The medium was adjusted to $\mathrm{pH} 5.7$ before autoclaving. The medium was dispensed $(50 \mathrm{~mL})$ into Magenta jars $(400 \mathrm{~mL})$ with nonvented GA7 closures (Sigma). Proliferating cultures were maintained in a growth room with a $16-\mathrm{h}$ photoperiod $\left(47.1 \mu \mathrm{mol} \cdot \mathrm{m}^{-2} \cdot \mathrm{s}^{-1}\right.$, vita-Lite $\left.40 \mathrm{~W}\right)$ at $24{ }^{\circ} \mathrm{C}$.

Explants were harvested for rooting from vigorously proliferating cultures. Individual explants $(1.0-1.5 \mathrm{~cm}$ length, with apical meristem) were removed from proliferating clumps and placed on 1/2 strength Murashige and Skoog medium supplemented with $2 \%$ sucrose, $2.5 \mu \mathrm{M}$ indolebutyric acid, and $0.7 \%$ agar gel in $20 \times 150 \mathrm{~mm}$ culture tubes topped with Kimble PM caps. Cultures were then placed in the dark for $14 \mathrm{~d}$ at $24^{\circ} \mathrm{C}$. Explants were then returned to the lighted growth chamber (16-h photoperiod) where root initiation began. The rooting treatment was started with an excess of explants so that 15 actively growing and well-rooted clones could easily be selected for Armillaria inoculation at a later date.

Three Armillaria isolates (two A. mellea and one $A$. tabescens) were inoculated separately to eight plant genotypes, in each of three experiments. The two isolates of $A$. mellea, Sac304 and Sol310, were recovered from symptomatic cherry and French prune, respectively (Sacramento County, CA, and Solano County, CA, respectively). Of our collection of $16 \mathrm{~A}$. mellea isolates from Prunus, these two isolates exhibited similar growth in culture (data not shown). Also, exhibiting similar growth in culture was one isolate of A. tabescens, SC4 (aka SC.LD1.02), which was recovered from symptomatic peach in Greenville County, SC (Schnabel et al., 2005). Inoculum was prepared by homogenizing for $30 \mathrm{~s}$ a 7 -d culture grown in potato dextrose broth (PDB) with $2.5 \mathrm{~mm}$ sodium acetate $\left(25^{\circ} \mathrm{C}, 100 \mathrm{rpm}\right)$ and then transferring with a sterile $1-\mathrm{mL}$ glass pipette $200 \mu \mathrm{L}$ of the resulting homogenate (i.e., mycelial fragments) per plant onto the surface of the plant growth medium (Baumgartner et al., 2013). Noninoculated controls were inoculated with $200 \mu \mathrm{L}$ sterile PDB. In this way, there were four inoculation treatments: Sac304, Sol310, SC4, and noninoculated controls.

For each of the three experiments, there were six replicate plants per plant genotype $\times$ inoculation-treatment combination (8 plant genotypes $\times 4$ inoculation treatments $\times 6$ replicate plants $=192$ total plants per experiment). Percent mortality was calculated as the proportion of inoculated plants that died within 2 months postinoculation out of the total number inoculated. Infection was confirmed by recovery of the pathogen in culture at the time of mortality or at 2 months postinoculation (whichever came first). Roots were separated from the plant growth medium by submerging the root system embedded within the medium in sterile water and then using a forceps and scalpel to gently scrape pieces of medium from the roots. Four root tips per plant were plated on water agar within $2 \mathrm{~d}$ of plant mortality. After $10 \mathrm{~d}$ of incubation at $25{ }^{\circ} \mathrm{C}$, cultures were examined for Armillaria colonies with the following characteristics: colony diameter of $\approx 2 \mathrm{~cm}$, regular colony margin, clampless hyphae embedded in the agar, sparse white aerial hyphae, absence of spores/spore-bearing structures, and the possible presence of immature rhizomorphs (white when embedded in the agar, black when above the surface). Root tips gathered from noninoculated plants were examined in this same manner on the day of inoculation and at 2 months postinoculation, in each of the three experiments $(n=6$ plants per genotype per experiment).

Statistical analyses. Analysis of variance (ANOVA) was used to determine the effects of the independent experiments (i.e., 1, 2, or 3), plant genotype (Bright's 5, Empyrean 1, Hansen 536, Krymsk 1, Krymsk 86, Lovell, Marianna 2624, and Nemaguard), inoculation treatment (SC4, Sac304, Sol310, or noninoculated), and their interactions on percent mortality. ANOVA was performed using the MIXED procedure in SAS, with Kenward-Roger as the denominator df method (Littell et al., 1996). All main and interaction effects were considered fixed. $F$ values with $P<0.05$ were considered significant. Before ANOVA, homogeneity of variance across treatments was confirmed (Box et al., 1978). After ANOVA, for significant effects $(P<0.05)$, differences among means were assessed based on the presence/absence of overlap of their $95 \%$ confidence intervals, and means without overlapping intervals were considered significantly different (Westfall et al., 1999).

\section{Results}

The ranking of relative resistance of Marianna 2624 as greater than that of Nemaguard comes primarily from field observations (Thomas et al., 1948). A preliminary experiment was conducted to confirm differences in mortality between our clonally propagated Nemaguard and Marianna 2624, propagated as described earlier. By 3 weeks postinoculation, the entire layer of the plant growth medium became colonized by Armillaria, and the first plants began to succumb to infection at 1 month postinoculation (data not shown). Nonetheless, differences in mortality between the two rootstocks were not significant until 2 months postinoculation. At this point, noninoculated Nemaguard and Marianna 2624 showed symptoms of nutrient deficiency, and so the assay was ended.

All noninoculated plants were free of Armillaria, as expected, based on no recovery of the pathogen from roots plated at 2 months postinoculation. Also, there was no mortality among noninoculated plants. Armillaria isolates were recovered in culture from roots of all inoculated plants, either at the time of mortality or at 2 months postinoculation.

ANOVA identified significant differences in percent mortality between plant genotypes $(P<0.0001)$ and Armillaria isolates $(P<$ $0.0001)$. With no interaction between plant genotype and isolate $(P=0.9)$, the order of genotypes starting with the most resistant was as follows: Krymsk 86, Krymsk 1, Marianna 2624, Lovell, Empyrean 1, Nemaguard, Bright's 5, and Hansen 536. On a per isolate basis, there were subtle differences in this order of relative resistance, especially among the most susceptible genotypes (Table 1). Nonetheless, for all three isolates, mean comparisons identified Krymsk 86 as having the lowest levels of mortality, Marianna 2624 and Lovell as having intermediate levels, and Hansen 536 as having the highest levels (Table 2; Fig. 1). There were no significant main or interaction effects of experiment $(P$ values all $\geq 0.6)$. Together, the Krymsk genotypes had significantly lower mortality than all other rootstocks and were even more resistant than the resistant control, Marianna 2624 (63\% mortality; $n=54$ plants, summed across all three isolates and all three experiments). Marianna 2624 was 
Table 1. Parentage of clonally propagated Prunus genotypes inoculated with Armillaria. Species of plum are in boldface text.

\begin{tabular}{ll}
\hline Rootstock & \multicolumn{1}{c}{ Parentage } \\
\hline Bright's 5 & Peach $\times$ Almond \\
Empyrean 1 (aka Barrier 1) & Peach $\times$ Prunus davidiana \\
Hansen 536 & {$[$ Okin. $\times($ P. davidiana $\times$ Pe PI 6582 $)] \times$ Almond } \\
Krymsk 1 (aka VVA 1) & Prunus tomentosa $\times$ Prunus cerasifera \\
Krymsk 86 (aka Kuban 86) & Peach $\times$ P. cerasifera \\
Lovell & Peach \\
Marianna 2624 & P. cerasifera $\times$ Prunus munsoniana \\
Nemaguard & Peach $\times$ P. davidiana \\
\hline
\end{tabular}

Table 2. Percent mortality of each plant genotype at 2 months postinoculation, for each of one isolate of Armillaria tabescens (SC4) and two isolates of Armillaria mellea (Sac304 and Sol310) versus noninoculated controls. Each cell is the mean of 18 observations, averaged across three replicate experiments $(n=6$ plants per isolate $\times$ plant genotype, per experiment $)$.

\begin{tabular}{lcccc}
\hline & \multicolumn{4}{c}{ Percent mortality at 2 months postinoculation $^{2}$} \\
\cline { 2 - 5 } Plant genotype & SC4 & Sac304 & Sol310 & Noninoculated \\
\hline Krymsk 86 & $8.34 \mathrm{a}$ & $38.64 \mathrm{a}$ & $35.00 \mathrm{a}$ & 0 \\
Krymsk 1 & $25.00 \mathrm{ab}$ & $45.00 \mathrm{ab}$ & $37.50 \mathrm{ab}$ & 0 \\
Marianna 2624 & $44.22 \mathrm{ab}$ & $75.56 \mathrm{ab}$ & $69.63 \mathrm{ab}$ & 0 \\
Lovell & $46.67 \mathrm{ab}$ & $85.36 \mathrm{ab}$ & $83.34 \mathrm{ab}$ & 0 \\
Empyrean 1 & $50.00 \mathrm{ab}$ & $100.00 \mathrm{~b}$ & $83.33 \mathrm{ab}$ & 0 \\
Nemaguard & $68.55 \mathrm{~b}$ & $92.80 \mathrm{~b}$ & $92.27 \mathrm{~b}$ & 0 \\
Bright's 5 & $66.67 \mathrm{~b}$ & $100.00 \mathrm{~b}$ & $95.00 \mathrm{~b}$ & 0 \\
Hansen 536 & $72.92 \mathrm{~b}$ & $94.45 \mathrm{~b}$ & $100.00 \mathrm{~b}$ & 0 \\
\hline
\end{tabular}

${ }^{\mathrm{z}}$ Means in the same column with different letters are significantly different, based on lack of overlap of their $95 \%$ confidence intervals $(P<0.05)$.

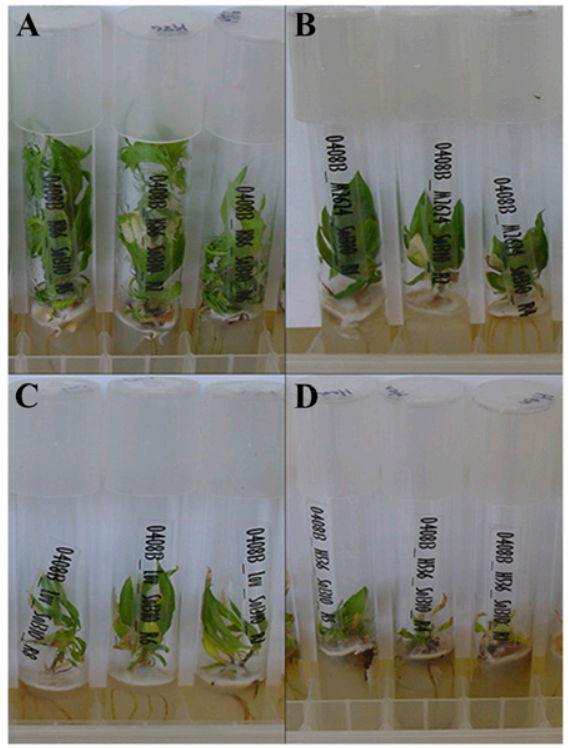

Fig. 1. Mortality among almond rootstocks in our growth chamber assay was as follows: (A) lowest for Krymsk 86, (B) moderate for Marianna 2624 and (C) Lovell, and (D) highest for Hansen 536. Images are representative of a subset of these four rootstocks inoculated with Armillaria mellea isolate Sol310 at 2 months postinoculation, during the first of three replicate experiments. The pathogen is visible on the surface of the tissue culture medium as white to tan-colored aerial mycelium.

statistically significantly more resistant than the susceptible control Nemaguard, which had $85 \%$ mortality. Hansen 536 and Bright's 5, with $89 \%$ and $87 \%$ mortality, respectively, were not significantly different from Nemaguard.
There were similar levels of mortality among plants inoculated with the two isolates of $A$. mellea, averaging $79 \%$ for Sac304 and $75 \%$ for Sol310 $(n=144$ plants, summed across all eight plant genotypes and all three experiments). Armillaria tabescens isolate SC4 was significantly less virulent, with $48 \%$ mortality $(n=144$ plants, summed across all eight plant genotypes and all three experiments). All Empyrean 1 and Bright's 5 plants inoculated with Sac304 and all Hansen 536 plants inoculated with Sol310 died by 2 months postinoculation, in all three experiments (Table 2). By contrast, the highest level of mortality for SC4 inoculations was observed in Hansen 536 at $73 \%(n=18$ plants, summed across all three experiments). Nonetheless, we found similar relative resistance among plant genotypes for $A$. tabescens isolate SC4 in terms of much lower mortality for the Krymsk genotypes compared with all others.

\section{Discussion}

California almond growers are not satisfied replanting all Armillaria-infected sites with Marianna 2624 because it is incompatible with some popular almond cultivars, namely, Nonpareil (Kester and Grasselly, 1987), the most widely planted almond cultivar. It also sprouts multiple shoots (suckers) from its roots, making harvest off the orchard floor more difficult. In our evaluation of eight almond rootstocks, Krymsk 86 had the lowest mortality, and this finding was consistent for two isolates of $A$. mellea and one isolate of A. tabescens, in three replicate experiments. The broad range of resistance we found among the eight rootstocks, ranging from $27 \%$ to $89 \%$ mortality $(n=54$ plants per rootstock, averaged across isolates and experiments), is consistent with past field trials with Prunus (Beckman et al., 1998; Beckman and Pusey, 2001; Guillaumin et al., 1989). In one field trial, over 100 peach and plum lines, planted in field soil where $A$. tabescens inoculum was present, were evaluated within nine years of planting (Beckman et al., 1998). The authors note that common rootstocks for peach in the southeastern United States, Lovell and Nemaguard (propagated on a commercial basis as seedlings), had similar levels of survival at $36 \%$ and $33 \%$, respectively. We had comparable findings after 2 months for both $A$. tabescens and A. mellea in our growth chamber experiment, albeit for clonally propagated selections of Lovell and Nemaguard, under much greater inoculum pressure.

Armillaria mellea and A. tabescens have different geographic ranges (Coetzee et al., 2011). As such, no field trial has evaluated these two species. Nonetheless, we can make some general comparisons among different field trials, which share in common some of the same Prunus rootstocks. Field trials in the southeastern United States have identified new rootstocks for peach, plum hybrids 'MP-29' (Prunus umbellata $\times$ peach) and 'Sharpe' (Prunus angustifolia $\times$ unknown plum species), with resistance to $A$. tabescens (Beckman, 2008; Beckman et al., 2012). In general, their results for these two new rootstocks are in agreement with an earlier field trial in A. tabescens-infected soil in that Prunus with various plum parents (e.g., 'Blue Goose' and 'Edible Sloe') were more resistant than those with a peach background (e.g., Nemaguard) (Beckman et al., 1998). In our growth chamber assay, we found similar results on plum parentage for both $A$. mellea and $A$. tabescens: lower mortality for all three rootstocks with $P$. cerasifera (aka Myrobalan plum) as a parent (Krymsk 86, Krymsk 1 , and Marianna 2624). These findings are consistent with past research on $A$. mellea, in which Myrobalan parentage in Marianna 2624, also shared with 'Myran' and 'Ishtara', was associated with very low levels of mortality in a field trial with controlled inoculations of A. mellea (Guillaumin et al., 1989).

Our findings are in contrast to past research on A. tabescens, in which Marianna 2624, 'Myran', and 'Ishtara' all performed worse than Lovell in a field trial with soil naturally infected with $A$. tabescens (Beckman and Pusey, 2001). Nonetheless, Marianna 2624 may have performed poorly against $A$. tabescens in the field because of interactions with abiotic factors (climate, soil $\mathrm{pH}$, etc.); other diseases, namely, Peach tree short life (PTSL) (Beckman et al., 1998), a disease complex incited by the bacterial canker pathogen Pseudomonas syringae pathovar syringae van Hall and exacerbated by ring nematode Mesocriconema xenoplax (Ritchie and Zehr, 1995); or both. Indeed, trees grafted to Marianna 2624 and other plum rootstocks are more susceptible to bacterial canker than those on peach rootstocks (Teviotdale and Kirkpatrick, 2002), and Marianna 2624 has been shown to be 
very susceptible to M. xenoplax (McKenry et al., 2007). Alternatively, the $A$. tabescens isolate we used, SC4, is highly virulent compared with the population of $A$. tabescens isolates present in the field trials cited earlier. Certainly, we selected SC4 strictly based on its similar in vitro growth to our fastest growing A. mellea isolates from Prunus.

Our growth chamber assay is much more simplistic than a field trial and, thus, our findings are too preliminary for making planting decisions in almond orchards just yet. Being able to complete the assay in the course of 1 year is an advance that allows researchers to screen through new almond rootstocks, albeit those that root well in tissue growth medium, to select promising genotypes for validation of resistance in field trials. However, replicated field trials are much better than our growth chamber assay at evaluating rootstocks in variable soils and climates, under commercial orchard management practices, and they allow for exposure to other biotic factors, all of which help determine the suitability of a rootstock. Our growth chamber assay was reliable, in terms of infecting all inoculated plants, and brought about repeatable mortality levels across replicate experiments. However, the greenhouse assay for Armillaria, in which the plant is rooted in soil and the inoculum consists of wood colonized by the pathogen, may better reflect what happens in the field when a root grows into contact with a residual root. With all root surfaces in contact with Armillaria mycelium, it is hard to account for the effect of vigor, for example, which would be better expressed in potted plants and certainly in a field experiment. Given the plantlets are only a few weeks old at the time of inoculation in our growth chamber assay, we must assume that the resistance expressed by their herbaceous roots is similar to that of woody roots.

In our growth chamber assay, even the resistant control Marianna 2624 had high levels of mortality, ranging among Armillaria isolates from $44 \%$ to $76 \%$. Such high inoculum pressure may mistakenly eliminate from further evaluation plant material that would be resistant in a field trial. A modification to the assay to help address this issue would be adding isolates which express a range of virulence, rather than selecting isolates with similarly high growth rates in vitro, which was our criterion. Another means of addressing the artificially high inoculum pressure in our assay is to use as a control (instead of noninoculated plants) a saprophytic species of Armillaria, such as $A$. gallica. Mortality caused by a saprophyte or a weak pathogen could provide a reference for whether our assay artificially favors root infection, which is not biologically relevant. Alternatively, given that Marianna 2624 is known to be resistant from field trials and if we had replicated our study with the same rootstocks and Armillaria isolates in the field, we could have established a threshold level of mortality based on that of Marianna 2624. All rootstocks with similar or lower levels of mortality would, thus, be considered resistant.

The rootstocks selected for this study were focused on almond production, which is widespread in California. Certainly, some of the same rootstocks have been studied in the southeastern United States, namely, those to which peach scions are typically grafted (e.g., Lovell and Nemaguard) (Beckman and Pusey, 2001). Our inclusion of such rootstocks and $A$. tabescens in the experimental design was meant to determine whether our growth chamber assay reflected findings from previous field trials (Beckman et al., 1998). As such, it is difficult to extend our findings to peach production in the southeastern United States. First, our study did not include 'Guardian', one of the most widely planted Prunus rootstocks in the southeastern United States (Beckman and Pusey, 2001). PTSL resistance in 'Guardian' drives its popularity as a peach rootstock in the southeastern US, but it is rarely planted in California, where nonetheless the pathogens associated with PTSL ( $P$. syringae pathovar syringae and $M$. xenoplax) cause similar symptoms (Ritchie and Zehr, 1995). Second, some of the rootstocks we examined (namely, the peach $\times$ almond hybrids, Bright's 5 and Hansen 536) induce high scion vigor, which is preferable for almond production, but is avoided in peach production (Layne, 1987).

For management of Armillaria root disease, proper sanitation is still an important aspect of site preparation, followed by using a resistant rootstock. To further reduce inoculum concentrations, soil fumigation will minimize the chances of infection. However, as there are also no convenient postinfection methods to eradicate the pathogen from infected trees, a continued focus on identifying Armillaria-resistant almond rootstocks, using the approach reported here to assist breeding programs in screening through many possible sources of resistance for crosses and their progeny, may identify rootstocks that resist not only this pathogen, but also additional root pathogens.

\section{Literature Cited}

Adaskaveg, J.E., H. Forster, L. Wade, D.F. Thompson, and J.H. Connell. 1999. Efficacy of sodium tetrathiocarbonate and propiconazole in managing Armillaria root rot of almond on peach rootstock. Plant Dis. 83:240-246.

Baumgartner, K. 2004. Root collar excavation for postinfection control of Armillaria root disease of grapevine. Plant Dis. 88:1235-1240

Baumgartner, K., R. Bhat, and P. Fujiyoshi. 2010. A rapid infection assay for Armillaria and realtime PCR quantitation of the fungal biomass in planta. Fungal Biol. 114:107-119.

Baumgartner, K., M.P.A. Coetzee, and D. Hoffmeister. 2011. Secrets of the subterranean pathosystem of Armillaria. Mol. Plant Pathol. 12:515-534.

Baumgartner, K., P.T. Fujiyoshi, G.T. Browne, C. Leslie, and D.A. Kluepfel. 2013Evaluating paradox walnut rootstocks for resistance to Armillaria root disease. HortScience 48:68-72.

Baumgartner, K. and D.M. Rizzo. 2002. Spread of Armillaria root disease in a California vineyard. Amer. J. Enol. Viticult. 53:197-203.
Beckman, T.G. 2008. 'Sharpe', a clonal plum rootstock for peach. HortScience 43:2236-2337.

Beckman, T.G., J.X. Chaparro, and W.B. Sherman. 2012. 'MP-29', a clonal interspecific hybrid rootstock for peach. HortScience 47:128-131.

Beckman, T.G., W.R. Okie, A.P. Nyczepir, P.L. Pusey, and C.C. Reilly. 1998. Relative susceptibility of peach and plum germplasm to Armillaria root rot. HortScience 33:1062-1065.

Beckman, T.G. and P.L. Pusey. 2001. Field testing peach rootstocks for resistance to Armillaria root rot. HortScience 36:101-103.

Bliss, D.E. 1951. The destruction of Armillaria mellea in citrus soils. Phytopathology 41:665-683.

Box, G.E.P., W.G. Hunter, and J.S. Hunter. 1978. Statistics for experimenters: An introduction to design, data analysis, and model building. Wiley, New York, NY.

Coetzee, M.P.A., P. Bloomer, M.J. Wingfield, and B.D. Wingfield. 2011. Paleogene radiation of a plant pathogenic mushroom. PLoS One 6:e28545.

Elias-Roman, R.D., R.A. Guzman-Plazola, N.B. Klopfenstein, D. Alvarado-Rosales, G. Calderon-Zavala, J.A. Mora-Aguilera, M.S. Kim, and R. GarciaEspinosa. 2013. Incidence and phylogenetic analyses of Armillaria spp. associated with root disease in peach orchards in the State of Mexico, Mexico. For. Pathol. 43:390-401.

Guillaumin, J.J., J. Pierson, and C. Grassely. 1989. The susceptibility of different Prunus species used as stone fruit rootstocks to Armillaria mellea (sensu stricto). Seventh International Conference on Root and Butt Rots. International Union of Forestry Research Organizations, Vernon and Victoria, BC, Canada.

Kable, P.F. 1974. Spread of Armillariella sp. in a peach orchard. Trans. Brit. Mycol. Soc. 62:89-98.

Kester, D.E. and C. Grasselly. 1987. Almond rootstocks, p. 265-293. In: R.C. Rom and R.F. Carlson (eds.). Rootstocks for fruit crops. Wiley, New York, NY.

Layne, R.E.C. 1987. Peach rootstocks, p. 185-216. In: R.C. Rom and R.F. Carlson (eds.). Rootstocks for fruit crops. Wiley, New York, NY.

Littell, R.C., G.A. Milliken, W.W. Stroup, and R.D. Wolfinger. 1996. SAS system for mixed models. SAS Institute Inc., Cary, NC.

Mansilla, J.P., O. Aguin, and M.J. Sainz. 2001. A fast method for production of Armillaria inoculum. Mycologia 93:612-615.

McKenry, M.V., R. Duncan, P.S. Verdegaal, J. Grant, M. Viveros, J. Connel, and J. Ireland. 2007. Development of nematode/rootstock profiles for 40 rootstocks with the potential to be an alternative to Nemaguard. Almond Research Reports. Almond Board of California.

Munnecke, D.E., M.J. Kolbezen, W.D. Wilbur, and H.D. Ohr. 1981. Interactions involved in controlling Armillaria mellea. Plant Dis. 65:384-389.

Murashige, T. and F. Scoog. 1962. A revised medium for rapid growth and bioassays with tobacco tissue culture. Physiol. Plant 15:473-497.

Qin, G.F., J. Zhao, and K. Korhonen. 2007. A study on intersterility groups of Armillaria in China. Mycologia 99:430-441.

Quoirin, M. and P. Lepoivre. 1977. Improved medium for in vitro culture of Prunus sp. Acta Hon. 78:437-442

Ritchie, D.F. and E.I. Zehr. 1995. Compendium of stone fruit diseases, p. 45-46. In: J.M. Ogawa, E.I. Zehr, G.W. Bird, D.F. Ritchie, K. Uriu, and J.K. Uyemoto (eds.). American Phytopathological Society Press, St. Paul, MN.

Rizzo, D.M., E.C. Whiting, and R.B. Elkins. 1998. Spatial distribution of Armillaria mellea in pear orchards. Plant Dis. 82:1226-1231. 
Sasaki, K. and Y. Jinno. 1975. Occurrence of Armillaria root rot of cherry orchards in Asakawa, Japan. Forest Pests 24:50-52.

Schnabel, G., P. Agudelo, G.W. Henderson, and P.A. Rollins. 2012. Aboveground root collar excavation of peach trees for Armillaria root rot management. Plant Dis. 96:681-686.

Schnabel, G., J.S. Ash, and P.K. Bryson. 2005. Identification and characterization of Armillaria tabescens from the southeastern United States. Mycol. Res. 109:1208-1222.

Singh, P. 1980. Armillaria root rot: Artificial inoculation and development of the disease in greenhouse. Eur. J. Forest Pathol. 10:420 431.

Teviotdale, B.L. and B.C. Kirkpatrick. 2002. Compendium of nut crop diseases in temperate zones, p. 32-33. In: B.L. Teviotdale, T.J.
Michailides, J.W. Psheidt (eds.). Amer. Phytopathol. Soc. Press, St. Paul, MN.

Thomas, H.E., C. Roberts, and A. Amstutz. 1948. Rootstock susceptibility to Armillaria mellea. Phytopathology 38:152-154.

Westfall, P.H., R.D. Tobias, D. Rom, R.D. Wolfinger, and Y. Hochberg. 1999. Multiple comparisons and multiple tests. SAS Inst. Inc., Cary, NC. 